\title{
Original article \\ The influence of kihap on the impact of Dolio-chagui kicks in taekwondo
}

\author{
Rodrigo Dias Martins \\ Debora Cantergi \\ Jefferson Fagundes Loss \\ Federal University of Rio Grande do Sul at Porto Alegre, Brazil
}

\begin{abstract}
The kihap is a technique used in several oriental martial arts. It is a yell used by practitioners with the expectation of enhancing the force of a hit. However, the real effect of using the kihap is unknown. Therefore, this study aims to compare the peak of acceleration of the Dolio-chagui kick in taekwondo performed with and without the use of kihap. Twenty two experienced taekwondo practitioners performed 30 kicks each against a punching bag, alternating in random order with and without kihap, while the acceleration of the punching bag was measured. A $t$-test was used to compare the difference between the mean acceleration in both conditions. Higher values were found with the use of kihap $(7.8 \pm 2.8 \mathrm{~g})$ than without the use of kihap $(7.1 \pm 2.4 \mathrm{~g}), p<0.01, r=0.57$. The results indicate that kihap enhances the impact of the kick.
\end{abstract}

Keywords: taekwondo, psych-up, martial art, biomechanics, kihap

Resumo - "A influência do kihap sobre o impacto de chutes Dolio-Chagui no taekwondo." O kihap é uma técnica utilizada em diversas artes marciais orientais. Ele é um grito utilizado pelo praticante com a expectativa de aumentar a força do golpe. Entretanto, o real efeito do uso do kihap é desconhecido. Assim, esse estudo tem por objetivo comparar o pico de aceleração do chute Dolio-chagui do taekwondo realizado com e sem o uso de kihap. Vinte e dois praticantes experientes de taekwondo realizaram 30 chutes contra um saco de pancadas, alternando em ordem randomizada com e sem o uso do kihap, enquanto a aceleração do saco de pancadas foi mensurada. Um teste- $t$ foi utilizado para comparar a diferença entre a aceleração média em ambas as condições. Valores mais altos foram encontrados com o uso do kihap $(7,8 \pm 2,8 \mathrm{~g})$ do que sem o uso do kihap $(7,1 \pm 2,4 \mathrm{~g}), p<0,01, r=0,57$. Os resultados indicam que o kihap aumenta o impacto do chute.

Palavras-chave: taekwondo, psych-up, arte marcial, biomecânica, kihap

Resumen- - "La influencia de kihap sobre el impacto de las patadas Dolio-Chagui en taekwondo." El kihap es una técnica utilizada en varias artes marciales orientales. Es un grito utilizado por los practicantes con la expectativa de mejorar la fuerza de un golpe. Sin embargo, se desconoce el efecto real de la utilización del kihap. Por lo tanto, este estudio tiene como objetivo comparar el pico de la aceleración de la patada Dolio-chagui en taekwondo realizado con y sin el uso del kihap. Veintidós practicantes de taekwondo experimentados realizaron 30 patadas cada uno contra un saco de boxeo, alternando en orden aleatorio con y sin kihap, mientras la aceleración del saco de boxeo fue medida. Se utilizó una prueba t para comparar la diferencia entre la aceleración media en ambas condiciones. Los valores más altos fueron encontrados con el uso de kihap $(7,8 \pm 2,8 \mathrm{~g})$ que sin el uso de kihap $(7,1 \pm 2,4 \mathrm{~g}), p<0,01, r=0,57$. Los resultados indican que el kihap mejora el impacto de la patada.

Palabras clave: taekwondo, psych-up, arte marcial, biomecánica, kihap

\section{Introduction}

Taekwondo is a martial art that originated in Korea during the twentieth Century from the Taekkyon, an ancient Korean martial art that arose around 37 BCE (Lee \& Bairner, 2009; Pieter, 2009). Although both hands and feet may be used for hitting the opponent (Hsiao, Lin, \& Chang, 2010), in competition, more kicks are used than punches. Frequently, in combat all the points counted for an athlete are scored through kicks, which have been observed since the 2000 Olympic games competition, when taekwondo was introduced (Bridge, Jones, \& Drust, 2011; Kazemi, Casella, \& Perri, 2009; Kazemi, Perri, \& Soave, 2010; Mohsen, Judith, Christopher, \& Anthony, 2006). Among the kicks in taekwondo, the Dolio-chagui kick (Figure 1) is one of the most used by athletes during competitions, and it has consequently been investigated in biomechanics research (Falco et al. 2009; Kim, Kim, \& Im, 2011; McGill, Chaimberg, Frost, \& Fenwick, 2010; O’Sullivan et al. 2009;). This kick is 
characterized by a rotation of the body while the leg is in the air, with the impact happening with the leg in full extension and the instep hitting the target (Park, Park, \& Gerrard, 2009).

Similar to other sports activities that require muscle power, taekwondo athletes yell during a hit, with the aim of performance enhancement (McGill et al., 2010). Also, during a combat situation, yelling is also used in order to intimidate the opponent or for calling the judges attention, for instance. In several martial arts yelling during the strike has been used for centuries, which in Korean martial arts like taekwondo is called kihap.

Eastern martial arts are said to transcend the notion of punching and kicking, usually attributed to combat sports (Seitz, Olson, Locke, \& Quam, 1990). Eastern martial arts include the notion of Ki. $\mathrm{Ki}$ is a complex principle which relates to a vital energy. This energy is used by the athletes by the means of the kihap in taekwondo, as an expression of the athlete and to discourage the rival during training and competition (Eroğlu, Diljin, \& Lütfi, 2006). Although this is an established idea in eastern knowledge, it has not been studied in scientific literature to some extent.

Studies that have verified the use of yells in force production are inconclusive. Martial arts practitioners enhanced their force production during handgrips when the yell was performed (Welch \& Tschampl, 2012), and trained subjects produced higher force when performing elbow flexion during the repetition with the yell (Ikai \& Steinhaus, 1961). However, during the performance of deadlifts by experienced and inexperienced subjects, no difference was found between situations with or without the yell (Morales, Scott, \& Dennis, 1999). Most important, the influence of the yell

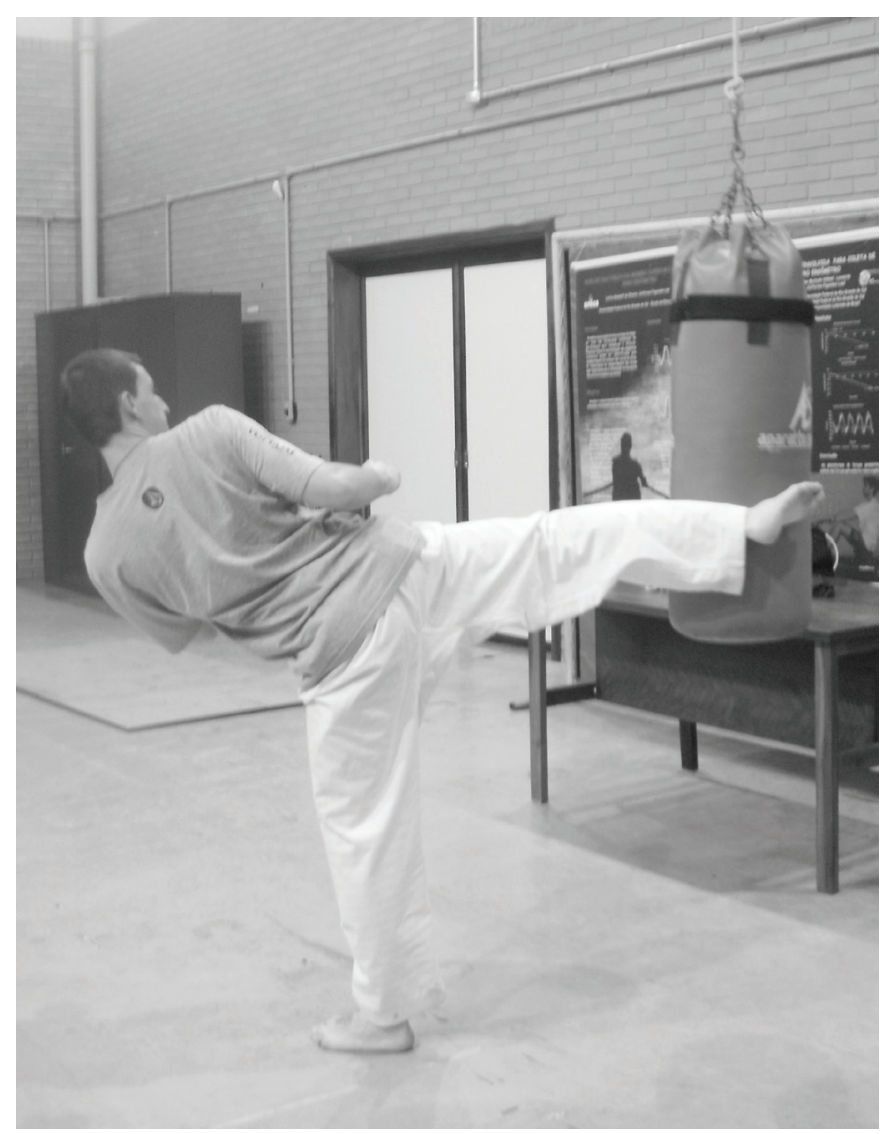

Figure 1. Round kick performed against a punching bag. in the force production of martial arts athletes during a specific combat gesture has not yet been verified. The main difference between the use of yells in eastern martial arts and other sports is the knowledge regarding the concept of Ki (Eroğlu et al., 2006).

The success of a hit may be evaluated by considering its effects, such as the impact force generated when two bodies collide, like the foot and the opponent or punching bag. In this case, the impact can be evaluated using force transducers, and the force peak or force rate can express impact.

Another way to evaluate impact is to measure the changes in body velocity during a short period of time, through body displacement and its derivations. Similarly to force measurements, the peak of acceleration during an impact situation is used to represent the event.

Therefore, this study aimed to compare the peak of acceleration as an indicator of impact of the Dolio-chagui kick of taekwondo performed with and without the use of kihap. We hypothesized that the kicks performed with the use of the kihap would present a higher mean peak of acceleration than would those performed without the kihap.

\section{Methods}

\section{Participants}

This study was approved by the local ethics committee and all participants gave written consent for their participation in the research.

The inclusion criteria were as follows: (a) have been training for at least 12 months, (b) have minimum graduation of $1^{\text {st }}$ Dan (black belt), (c) be experienced in the execution of the Doliochagui kick and (d) have been free of musculoskeletal injuries for the past six months. Following these criteria, the sample was composed of 13 male participants, all of whom were experienced taekwondo practitioners with $16.2 \pm 5.6$ years of practice, age of $33 \pm 10$ years, weight of $75.8 \pm 13.54 \mathrm{~kg}$ and height of $172.1 \pm 7.0 \mathrm{~cm}$. Among the 13 participants, two were $4^{\text {th }}$ dan, two were $3^{\text {rd }}$ dan, six were $2^{\text {nd }}$ dan and three were $1^{\text {st }}$ dan. Also, according to the international weight division, one participant was flyweight, four were featherweight, two were welterweight and six were heavyweight.

\section{Procedures}

After giving written consent, the participants were oriented to warm up for the time needed and to familiarize themselves with the data collection environment. Each participant performed a series of 30 Dolio-chagui kicks (round kick) of taekwondo with and without the use of kihap. The order of the kicks was previously raffled for randomization for each subject and the time allowed between kicks was free. The number of kicks was defined to be high enough to allow the natural variability of the series to assume a normal distribution but not too high that the participant would be fatigued by the end of the series. Participants were asked to perform the manoeuvre in maximum force, despite of the use of kihap. 
Data was collected using an accelerometer DeltaTron ${ }^{\circledR}$ (type 4507 B 006, Brüel\&Kjær) piezoelectric, calibrated by $500 \mathrm{mV} / \mathrm{g}$, with a capacity of up to $\pm 14 \mathrm{~g}$ and sample rate $2000 \mathrm{~Hz}$. The accelerometer was fixed in a specific site to a $25 \mathrm{~kg}$ punching bag that was used as a target. Participants were asked to kick the punching bag at the opposite side of the accelerometer attachment, which had a target printed so the kicks would be all to the same place. The punching bag could be moved up or down so that the target would be in the same height as the participant's waist. Once data collection began, the participant would position himself to perform the movement and before each kick one of the investigators indicated if it was to be performed with or without kihap. This position was to be kept throughout all kicks.

One evaluator who was a taekwondo instructor $\left(2^{\text {nd }}\right.$ Dan $)$ who has been in the sport for over 20 years and is experienced as a referee was responsible for evaluating whether the kick had been well performed and could be considered valid. The kick was excluded if the leg trajectory did not correspond to the kick characteristics. It was taken into consideration the angles of the knee, hip rotation, trajectory, and foot impact angle to the target. It was also considered the position about the target of the subject and the distance from the target. In cases where the kick was not valid, the peak was replaced by the performance of one more kick. This investigator did not participate in the data analysis. Only two subjects were asked to repeat one kick, because of the inappropriate starting position and for missing the target.

\section{Data analysis}

The acceleration data was collected as a single set of data for each subject. In the Matlab ${ }^{\circledR}$ software 7.5, peaks were obtained separately. The data was verified in the frequency domain using a Fast Fourier Transform procedure (Welch, 1967) and did not present any important noise, so no filtering or other processing was necessary. Peak values were then organized in the SPSS 18.0 software for statistical analysis.

\section{Pre-test}

Prior to data collection, a series of tests were performed in the laboratory in order to perfect the protocol that would be used. Once the protocol had been established, one subject (11.4 years of practice, 34 years old, $63 \mathrm{~kg}$ weight, $171 \mathrm{~cm}$ height, $2^{\text {nd }}$ Dan) performed the test twice, in different days. The mean results obtained in this pre-test were: Day 1 - with kihap: 9.8 $\mathrm{g}( \pm 2.2 \mathrm{~g})$; without kihap: $8.2 \mathrm{~g}( \pm 2.1 \mathrm{~g})$; Day 2 - with kihap: $10.0 \mathrm{~g}( \pm 3.2 \mathrm{~g})$; without kihap: $8.1 \mathrm{~g}( \pm 1.5 \mathrm{~g})$.

\section{Statistical analysis}

Shapiro-Wilk and Levene tests were used for verifying normality and homogeneity. A paired samples $t$-test was used for verifying the difference in acceleration peaks between the kicks performed with and without kihap. The level of significance adopted was $\alpha<0.05$.
Table 1. Mean and standard deviation values of the acceleration peak of the kicks performed with and without kihap, expressed in number of g.

\begin{tabular}{lll}
\hline & With kihap* & Without kihap \\
\hline Mean & 8.1 & 7.4 \\
SD & 3.0 & 2.6 \\
\hline
\end{tabular}

$* p<0.05$, significance difference between acceleration peaks.

\section{Results}

The mean and standard deviation values of the acceleration peaks of the Dolio-chagui kick performed with and without the use of kihap are presented in Table 1. The mean acceleration peak of the kick performed with kihap was significantly higher than that of the kick performed without kihap, at $t(12)=3.023$, $p<0,01$, with a large size effect, $r=0.66$ (Field, 2005).

\section{Discussion}

The present study aimed to compare the peak acceleration of the Dolio-chagui kick of taekwondo performed with and without the use of kihap. The acceleration at the moment of impact was used as an indication of the kick's impact. The results show that the mean acceleration peak of the kicks performed with kihap was significantly higher than that of the kicks performed without kihap.

Martial arts specific literature attributes to the kihap the capacity for enhancing the force, speed and precision of a hit, among other benefits, like breath control (McGill et al., 2010). The ability of the kihap to enhance speed and, consequently, the impact force of a hit is shown in the results of the present study.

The concept of $K i$ originates in eastern philosophy, and has been used in martial arts, as taekwondo, channelling it for the strike in order to amplify its effectiveness (Chun 1993). Although the effect of yelling in trained martial athletes performing specific movements has not been verified, its use in occidental sports without the understanding of the $K i$ for enhancing performance has been tested.

The use of yells in elite sports is evident, especially in sports that require explosive force, such as shot put, weight lifting and tennis serves (Welch \& Tschampl, 2012). Yelling is considered a cognitive technique of psychological stimulus that allows for performance enhancement (Ikai \& Steinhaus, 1961).

The effect of the use of cognitive stimulation techniques was evaluated in the performance of force production in the hand grip exercise (Welch \& Tschampl, 2012). Fifty subjects performed the exercise using a hand dynamometer in different situations, including with and without yelling. An enhancement of about $7 \%$ in the production of force in the situation with the yell in comparison to the situation without the yell was found. These results point in the same direction as the present study, when the performance of the Dolio-chagui kick with kihap showed acceleration about $10 \%$ higher than the acceleration in the kick without the kihap.

In addition, with the aim of evaluating the psychological limits of force production, Ikai and Steinhaus (1961) tested 
the maximum force production during elbow flexion. Several evaluations were performed, among which were the use of the yell during the test. An enhancement of about $12 \%$ in the elbow flexion performed with yelling was found in comparison to that without yelling (Ikai \& Steinhaus, 1961). It should be noted that this study sample comprised subjects not trained in the use of kihap. The authors suggested that the effect of yelling during the elbow flexion was enough to inhibit internal restrictions.

On the other hand, no difference was found in the performance of deadlift exercises by athletes and non-athletes with and without yelling (Morales et al., 1999). Although there was no significant difference, authors suggested that in sports like weight lifting, even the smallest changes may decide a finishing position or the winning of a medal, suggesting that the difference found was important (Morales et al., 1999).

It should be pointed out that the use of a single axis accelerometer is a limitation of the study, which was hoped to be minimized by a rigid control in the data collection and in the use of a paired t-test for statistical analysis. Future studies may explore the tridimensional characteristic of the acceleration.

In conclusion, the peak of acceleration of the Dolio-chagui kick of taekwondo was higher when the kick was performed with the use of kihap than when it was performed without the kihap, suggesting that yelling has the capacity of enhancing the kick's impact.

\section{References}

Bridge, C., Jones, M., \& Drust, B. (2011). The activity profile in international taekwondo competition is modulated by weight category. International journal of sports physiology and performance, 6(3), 344.

Chun, R. (1993). Advancing in tae kwon do. Boston, Mass, YMAA.

Eroğlu, E., Diljin, K. A., \& Lütfi, B. M. (2006). Elite tae kwon do athletes' satisfaction with custom-made mouthguards. Dental Traumatology 22(4), 193-197.

Falco, C., Alvarez, O., Castillo, I., Estevan, I., Martos, J., Mugarra, F., \& Iradi, A. (2009). Influence of the distance in a roundhouse kick's execution time and impact force in taekwondo. Journal of biomechanics 42(3), 242-248.

Field, A. (2005). Discovering Statistics Using SPSS. (2 ed.). London, United Kingdom: Sage Publications Ltd.

Hsiao, C.T., Lin, J.S., \& Chang, K.P. (2010). Taekwondo sport development: The case of Taiwan. OR insight, 23(3), 154-171.

Ikai, M. \& Steinhaus, A.H. (1961). Some factors modifying the expression of human strength. Journal of Applied Physiology, 16, 157-163.

Kazemi, M., Casella, C., \& Perri, G. (2009). 2004 Olympic tae kwon do athlete profile. The Journal of the Canadian Chiropractic Association, 53(2), 144-152.

Kazemi, M., Perri, G., \& Soave, D. (2010). A profile of 2008 Olympic taekwondo competitors. Journal of the Canadian Chiropractic Association, 54(4), 243.

Kim, Y.K., Kim, Y.H., \& Im, S.J. (2011). Inter-joint coordination in producing kicking velocity of Taekwondo kicks. Journal of Sports Science and Medicine 10, 31-38.

Lee, J.W. \& Bairner, A. (2009). The Difficult Dialogue: Communism, Nationalism, and Political Propaganda in North Korean Sport. Journal of Sport \& Social Issues, 33(4), 390-410.

McGill, S.M., Chaimberg, J.D., Frost, D.M., \& Fenwick, C.M.J. (2010). Evidence of a double peak in muscle activation to enhance strike speed and force: an example with elite mixed martial arts fighters. The Journal of Strength \& Conditioning Research, 24(2), 348.
Mohsen, K., Judith, W., Christopher, M., \& Anthony, R. W. (2006). A profile of olympic taekwondo competitors. Journal of Sports Science and Medicine, 5, 114-121.

Morales, Z., Scott, O., \& Dennis, G.O.C. (1999). Vocal disinhibition (grunting) does not increase dead lift force in college athletes or nonathletes Perceptual and motor skills, 89(1), 233-234.

O’Sullivan, D., Chung, C., Lee, K., Kim, E., Kang, S., Kim, T., \& Shin, I. (2009). Measurement and comparison of Taekwondo and Yongmudo turning kick impact force for two target heights. Journal of Sports Science and Medicine 8, 13-16.

Park, Y.H., Park, Y.H., \& Gerrard, J. (2009). Tae kwon do: the ultimate reference guide to the world's most popular martial art. New York, Infobase Publishing.

Pieter, W. (2009). Taekwondo. In R. Kordi (Ed.), Combat Sports Medicine (pp. 263-286).

Seitz, R.C., Olson, G.D., Locke, B., \& Quam, R. (1990). The martial arts and mental health: The challenge of managing energy. Perceptual and motor Skills 70(2), 459-464.

Welch, A.S., \& Tschampl, M., Welch, A.S., \& Tschampl, M. (2012). Something to Shout About: A Simple, Quick Performance Enhancement Technique Improved Strength in Both Experts and Novices. Journal of Applied Sport Psychology, 24(4), 418-428.

Welch, P. (1967). The use of fast Fourier transform for the estimation of power spectra: A method based on time averaging over short, modified periodograms. IEEE Transactions on Audio and Electroacoustics, 15(2), 70-73.

\section{Authors' note}

Rodrigo Dias Martins has a degree in physical education from the Federal University of Rio Grande do Sul (2013); martial arts degree in taekwondo, $2^{\circ}$ Dan from the Superior Institute of Taekwondo; Haedong Kundo, $1^{\circ}$ Dan from the United World Haedong Kundo Federation; and Hapkido, $1^{\circ} \mathrm{Gub}$ from the Um Yang Kwan Association of Hapkido.

Debora Cantergi has a degree in physical education from the Federal University of Rio Grande do Sul (2007) and a master's degree in Human Movement Science from the same university, in the area of biomechanics (2011).

Jefferson Fagundes Loss has a degree in electrical engineering from the Pontifical Catholic University of Rio Grande do Sul (1986), Master's and doctoral degrees in mechanical engineering from the Federal University of Rio Grande do Sul (1996 and 2001). He is currently an associate professor at the Physical Education School of the Federal University of Rio Grande do Sul. He teaches biomechanics, instrumentation and signal analysis at undergraduate and graduate levels (latu and strictu sensus). His main area of interested is the analysis of external forces acting on the human body and their respective implications on the muscle skeletal structures.

\section{Contact:}

Rodrigo Dias Martins

E-mail: rodtkd.martins@gmail.com

Manuscript received on May 15, 2013

Manuscript accepted on January 8, 2014

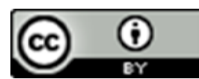

